О. М. Кібік, О. П. Подиерковний, В. О. Котлубай, Ю. В. Хаймінова, Ю. З. Драпайло, Ю. П. Постоленко, О. О. Брагарник, М. С. Козолуп

\title{
ОРГАНІЗАЦІЙНО-ПРАВОВІ ПЕРЕДУМОВИ ІНТЕНСИФІКАЦІї ЕКСПОРТНОЇ ДІЯЛЬНОСТі В УКРАЇНі
}

Проблема підвищення національної конкурентоспроможності протягом останніх десятиліть перебуває у центрі уваги урядів більшості зарубіжних країн. Основним індикатором конкурентоспроможності країни визнають іiі експортний потенціал та фактичний рівень його реалізації, що $\epsilon$ інструментом просування національних інтересів у масштабах світового господарства.

Експортний потенціал $є$ однією зі складових економічного потенціалу, який забезпечує, на відміну від інших складових (виробничого, трудового, природного, фінансового, інформаційного потенціалу тощо), процес реалізації товарів на зовнішньому ринку.

Розробка та реалізація стратегії підтримки національного експорту і відповідно посилення його позицій на світовому ринку є особливо актуальним питанням для сучасної України. Наша держава має переваги, які $\epsilon$ передумовами формування та реалізації іï експортного потенціалу. Такими перевагами є достатня чисельність кваліфікованої робочої сили, вигідне географічне положення, природні ресурси, індустріальний потенціал, достатньо високий рівень розвитку деяких галузей, наявність розвинутої транспортної системи, вагомі досягнення у сфері фундаментальних наукових досліджень тощо. Більшість 3 наведених переваг не використані в повній мірі у межах реалізації експортної стратегії України внаслідок незадовільного організаційно-правового забезпечення зазначеної сфери.

Питання розвитку експортної діяльності досліджувало багато науковців, зокрема: М. Беноа, ІІ. Брос'є, Ф. Буши, Є. Ган, О. Гаске, Ж. Ечкеназі, Л. Каруи, ІІ. Коломбель, А. Корбут, М. Корістон, Ж. Леонар, П. Лімузан, Е. Маршал, А. Михайлів, Ж. Нафіліан, О. Сизов, А. Терреноар, 
М. Трейсі, Л. Штріве та ін. В Україні цей напрямок розробляють І̇. Бураковський, П. Гайдуцький, В. Гончаренко, С. Дем'яненко, Е. Зінь, С. Зоря, С. Қваша, Іे. Кобута, М. Компанець, О. Лука, О. Олійник, С. Онисько, В. Рокоча, П. Саблук, В. Савчук, О. Тимків, А. Філіпенко, О. Юхновський та ін. Актуальні проблеми, які перешкоджають розвиткові українського експорту, досліджували В. Мовчан, Т. Мельник, Л. Ївашова, А. Мазаракі, Л. Кутідзе, Ю. Верланов, Н. Осадча, О. Школьний, І̇. Орлик, Н. Резнікова та ін.

Однак проблема розвитку експортного потенціалу України залишається вкрай актуальною. Комплексного вивчення потребують сучасні економіко-правові та організаційні умови розвитку українського експорту задля забезпечення передумов ефективного входження України у світову систему господарських зв'язків.

Метою статті $€$ визначення основних організаційно-правових передумов підвищення ефективності експортної діяльності в Україні.

Досвід економічно розвинених країн свідчить про те, що розвиток експортного потенціалу допомагає поліпшенню економічного становища як країни в цілому, так і окремих її регіонів. Тому розвинені країни більшу частину своєї продукції намагаються експортувати, ніж продавати на внутрішньому ринку. Тим самим рівень продукції повинен відповідати вимогам міжнародних ринків і бути конкурентоспроможним [1].

Поняття «експортний потенціал» переважно характеризується крізь призму категорій «здатність», «спроможність», «можливість». Частина науковців розглядає експортний потенціал як певну здатність виробляти та реалізовувати продукцію, мобілізувати економічні ресурси та використовувати їх з максимальною ефективністю, відтворювати конкурентні переваги на світовому ринку, контролювати максимально можливу частку ринку, розвиватися на світовому ринку, адаптуватися до вимог зовнішніх чинників [2, с. 69;3].

Академік Л. Іे. Абалкін розглядає економічний потенціал стосовно економіки країни, іï галузей та окремих підприємств як їх здатність виробляти продукцію, товари, послуги, задовольняти потреби населення та суспільства в цілому, забезпечувати розвиток виробництва та споживання [4, с. 384]. Саме тому, на нашу думку, необхідно розглядати експортний потенціал як складову економічного потенціалу країни, в якій відображаються можливості національної економічної системи інтегруватись у світовий економічний простір.

Експортний потенціал країни нерозривно пов'язаний із розробкою стратегії та тактики виходу перспективних видів товарів на зовнішні ринки, завдяки яким можна реалізувати місцеві товари.

Експортний потенціал держави визначається обсягами товарів, які можуть бути вироблені в економічній та соціальній сферах і реалізовані на світовому ринку з максимальною вигодою для країни [5].

Експортна стратегія має за мету стимулювання розвитку експорту країни у довгостроковій перспективі. Експортна стратегія визначається 
пріоритетними напрямками розвитку економіки та обов'язково має бути узгодженою з потребами виробників для найефективнішої реалізації переваг, що розкривають запропоновані напрямки. Це, у свою чергу, потребує визначення проміжних цілей та засобів їх досягнення. На практиці ця політика реалізується через утворення мережі відповідних інститутів, визначення їх функцій та підпорядкованості [6, с. 10-12]. У процесі розробки експортної стратегії необхідно визначити пріоритетні напрямки розвитку зовнішньоекономічних відносин з акцентом на експортно-стратегічні для України товари.

На нашу думку, слід виділити систему чинників, які визначають формування та розвиток експортного потенціалу країни. Серед них можна відокремити внутрішні та зовнішні, тому що експортний потенціал базується на національному підході щодо визначення можливостей виробництва і врахуванні конкурентних умов світового ринку щодо реалізації виробленої експортної продукції.

До внутрішніх чинників слід віднести, передусім, ресурсно-сировинний потенціал, можливості промислового виробництва і кадрове забезпечення; науковий та інвестиційно-інноваційний потенціал, законодавчу i нормативну базу та діяльність державних установ. До негативних чинників цієї групи можна віднести низький рівень конкурентоспроможності більшості українських підприємств, що $є$ реальними або потенційними експортерами; незадовільний фінансовий стан більшості підприємств, що обмежує можливості інвестування експортної діяльності; зростання витрат експортної діяльності; низький світовий рейтинг інвестиційної привабливості та надійності України; високий рівень оподаткування експортної діяльності.

Зовнішні чинники - це чинники ринкової дії (ємність, кон'юнктура ринку і умови конкуренції на ньому) та інституціональний чинник (система міжнародних інститутів з координації світових торговельних потоків).

Серед внутрішніх чинників більш детально розглянемо низький рівень конкурентоспроможності більшості українських експортоорієнтованих підприємств. Критичною проблемою, що має наслідком низький рівень конкурентоспроможності, є незадовільний стан відтворення капіталу та технологічної складової експортоорієнтованих підприємств (у першу чергу, в металургії, хімічній та транспортній галузях). Починаючи з 90-х рр. минулого століття низькотехнологічність свідчила не тільки про наростаючу відсталість (понад 90 \% господарства становлять III i IV технологічні уклади), а й про вкрай погане ставлення до виробничих фондів. Так звані ефективні власники не проводили модернізацію виробничого потенціалу, а по-хижацьки експлуатували наявні потужності.

Критичний стан національної економіки, що ускладнюється зовнішніми боргами та гострою нестачею фінансів, обумовлює необхідність не екстенсивного нарощування наявного виробничого потенціалу, а форму- 
вання моделі ефективного відтворення капіталу та модернізації технологій, заснованої на зміні поколінь технологічних укладів - низьких високими.

Поряд із традиційними видами експорту також необхідно створювати й виробництво нових видів продукції, що грунтуються на новітніх досягненнях науки і техніки.

Формування експортного потенціалу $є$ складним процесом, розвиток якого багато в чому визначають рівень застосованих технологій та інноваційність моделі відтворення капіталу експортоорієнтованих підприємств.

Сучасний відтворювальний процес включає в себе процес просування інновацій, що виявляється у впровадженні нових матеріалів і технологій. Вплив технологій на відтворювальний процес безпосередньо пов'язаний з інноваційним аспектом, оскільки позитивна технологічна динаміка забезпечується тільки при технологіях, що мають інноваційний характер. Переважання застарілих технологій консервує технологічну структуру відтворювальної системи і блокує інноваційний розвиток. У свою чергу, інноваційний потенціал і можливості інноваційного розвитку відтворювального процесу зумовлюються інституційною організацією національної економіки [7, с. 134]. Таким чином, рівень розвитку технологічної бази та стан інституційної структури визначають не тільки ефективність відтворювального процесу, а й соціально-економічний розвиток країни в цілому та можливість реалізації експортного потенціалу.

Практика інституційних реформ показує, що інституційні перетворення не забезпечують автоматично ефективної організації відтворювального процесу, а найчастіше сприяють збереженню або навіть посилюють інерційність розвитку економічної системи, яка замикається на неефективних нормах, що перешкоджають iї інноваційному розвитку [8, с. 10-12].

Дане питання особливо актуальне для вітчизняних економічних умов, оскільки трансформація економічних систем неминуче припускає інституційні зміни, які для успішного здійснення відтворювального процесу повинні доповнюватися технологічними змінами.

Технологічні та інституційні зміни є об’єктивною основою розвитку відтворювального процесу. Так, істотно різняться між собою способи застосування знарядь ручної праці, машин і автоматичних ліній. У всіх випадках існуючі інститути, в тому числі відносини власності на засоби виробництва, форми отримання прибутку, оплати праці тощо, повинні сприяти найбільш ефективному використанню продуктивних сил людських здібностей, знарядь праці, джерел енергії тощо. Поки це має місце, виробництво розвивається ефективно. Коли ж така відповідність порушується, це призводить до кризових явищ, інституційні відносини відстають від розвитку продуктивних сил, стають консервативною стороною виробництва, гальмуючи його розвиток і приводячи до суперечностей між організаційними формами і інститутами. Виникає явище інституційної інерції. 
Нові інститути, згідно з Д. Нортом, з'являються тоді, коли суспільство вбачає можливість отримання прибутку, який не може бути отриманий в умовах вже існуючої інституційної системи. Їншими словами, якщо виробничі фактори надають можливість збільшення доходів, а інституційні цьому перешкоджають, тоді великі шанси виникнення нових інститутів [9, с. 358].

Кожній відтворювальній системі притаманна певна система технологій, яку закріплює відповідний інституційний механізм. Система капіталу і технологій $є$ безпосереднім вираженням відтворювальних відносин, тому тільки створивши адекватну своєю природою систему технологій, відтворювальна система може повною мірою забезпечити реалізацію своєї сутності.

Відтворювальний процес в експортоорієнтованих галузях сьогодні часто відбувається на основі тих технологічних передумов, які були створені у радянський час. Перетворення, які відбуваються в матеріально-технічній базі, ще не можна розглядати як створення адекватної сучасному рівню НТП системи технологій і засобів праці. Ця обставина має обумовлювати вдосконалення технологій та оновлення капіталу. Паралельно з технологічним розвитком повинні відбуватися інституційні зміни, що позитивно відіб'ється на результативності відтворювального процесу, тому що в цьому випадку змінюються форми організації виробництва, перебудовуються системи освіти, створюються сприятливі умови для формування нових інвестиційних, галузевих і технологічних структур. Коли всі ланки відтворювальної системи еволюціонують у відповідності з новими технологічними вимогами, то відбувається скорочення витрат виробництва. Якщо ж конфлікт між новими технологіями та інституційним оточенням вирішити не вдається, то нові технології розвиваються у рамках старого технологічного укладу, що призводить до економічних втрат і неефективності відтворювального процесу.

Застосування певної технології протягом тривалого часу закріплює інститути, які визначають певне коло взаємодій економічних агентів у рамках відтворювального циклу, обумовленого даною технологією. Дії груп, що виграють від збереження сформованих інституційних і технологічних умов, створюють перешкоди для впровадження нових технологій за допомогою лобіювання своїх інтересів, тим самим формуючи інституційне середовище, не прийнятне для здійснення інноваційно спрямованого відтворення капіталу.

Таким чином, технологічні зміни неможливі без формування відповідних інституційних умов, які безпосереднім чином впливають на процеси капіталу експортоорієнтованих підприємств. У свою чергу, стан і можливі варіанти ефективної організації відтворювального процесу багато в чому визначаються змінами в технологічній структурі економіки.

Оскільки всі процеси створення наукового і технологічного знання, також як і процеси використання вже наявних технологій та їх адаптації, вимагають участі безлічі взаємодоповнюючих і взаємопов'язаних 
суб'єктів, необхідною є розробка комплексної стратегії інноваційно-технологічного розвитку відтворювальної системи, а потім проведення відповідної економічної політики. На інституціональному рівні це повинно реалізовуватися в планах технологічного розвитку, пов'язаних з розробкою прикладних досліджень, функціонування інституційного середовища та виробничо-технологічної інфраструктури. Необхідними $€$ відповідні макроекономічні умови, які повинні включати в себе, перш за все, ефективний механізм державної науково-технічної та промислової політики. При обгрунтуванні такої політики одним з найбільш важливих питань $€$ вибір напрямів і способів технологічного розвитку та структурно-технологічних перетворень.

Основними принципами даної стратегії має стати посилення координації діяльності органів державного управління та удосконалення нормативно-правової бази в галузі проведення інноваційної діяльності, впровадження міжнародних стандартів та рекомендацій; введення податкових пільг на проведення дослідних і конструкторських розробок, а також стимулювання рефінансування прибутку підприємств на інноваційну діяльність.

У сучасних умовах для реалізації стратегії інноваційно-технологічного розвитку відтворювальної системи головним організуючим елементом інституційної структури має виступати держава, яка має свідомо брати участь у процесі відбору інститутів і одночасно виступати як інституційний інноватор.

Основні підходи до формування даної стратегії мають включати комплекс взаємопов'язаних соціально-економічних, науково-технічних та організаційно-господарських заходів і завдань, спрямованих на досягнення конкретної кінцевої мети.

За даними митної служби України, за 2014 р. було експортовано 3 України товарів на суму майже 54 млрд дол., що на 14 \% менше, ніж у 2013 p.

За результатами 2014 р. експорт України в країни СНД упав на 7 млрд дол. Через заборони і обмеження Україна у 2014 р. поставила в Росію на 5,2 млрд дол. менше продукції. Очікування того, що скасування імпортних мит ЄС дасть можливість Україні компенсувати втрати на ринку СНД не виправдалися. Експорт України в країни ЄС зріс лише на 0,331 млрд дол. за рік. За грудень 2014 р. взагалі спостерігалося падіння експорту України в країни ЄС майже на 0,52 млрддол. порівняно 3 груднем 2013 р. [10].

Як відомо, світовий ринок поділений між країнами. У сучасних умовах існуючий поділ ринків змінити досить складно. Проблема гальмування зростання обсягу українського експорту в $Є С$ особливо актуальна на тлі закриття російського ринку. Внаслідок того, що ринок ЄС перенасичений своєю готовою продукцією, на сьогоднішній день Україна може постачати в ЄС тільки сировину. Тому основними товарами, що постачаються Україною на ринок $Є C$, $€$ кукурудза і чавун, що не може кон- 
курувати з ринками СНД, де Україна постачає готові продукти харчування, продукцію машинобудування і продукцію хімічної промисловості. Український експорт товарів істотно збільшився в Туреччину, Єгипет, Їндію, Їрак і Китай. На ринку США для українського експорту найбільші перспективи має продукція галузей агропромисловості, інформаційних технологій, ракетно-космічної. Експорт продукції металургії та важкої промисловості також $є$ цікавим для американського покупця [11].

У таких умовах необхідність зміцнення експортного потенціалу України обумовлена винятковою значущістю експорту як чинника відродження та розвитку національної економіки. У межах державного регулювання функціонування економічної системи має бути забезпечено підтримку вітчизняних експортерів. За умови такої підтримки може бути збільшено обсяги українського виробництва, суми податкових надходжень до бюджету та створено додаткові робочі місця тощо. Вичерпання екстенсивних факторів зростання українського експорту товарів сировинної групи, скорочення питомої ваги машинотехнічної продукції в національному експорті, постійне посилення ступеня міжнародної конкуренції на зовнішніх ринках на тлі активної державної підтримки експорту за кордоном і застосування розвиненими країнами захисних заходів в інтересах власних галузевих виробництв обумовлюють необхідність реалізації державних заходів сприяння розвитку прогресивної якісної структури експортного потенціалу України.

Аналіз світового досвіду показує, що практично всі країни здійснюють регулювання і стимулювання зовнішньоекономічної діяльності на макро- і мезорівнях. Підтримка експорту за кордоном реалізується через систему взаємодіючих і взаємопов'язаних між собою урядових і неурядових інституцій, до числа яких відносяться профільні міністерства і відомства, спеціалізовані агенції та експертні центри, фінансові структури, дипломатичні місії тощо.

Державне сприяння експорту здійснюється в досить розвиненому вигляді у багатьох розвинених країнах Америки, Європи та Азії. Найбільшої досконалості, як видається, держпідтримка досягла в США. Головним напрямком підтримки американського бізнесу за кордоном $€$ створення сприятливих інституційних умов компаніям США для реалізації вигідних комерційних проектів. Держдепартамент здійснює координацію зовнішньоекономічної діяльності всіх міністерств і відомств, державних організацій та їх представників за кордоном. 3 ініціативи Держдепартаменту проводяться засідання координаційних і консультативних комітетів з різних питань, що стосуються ЗЕД, за участю представників підприємницьких структур для врахування їх позиції щодо міжнародних заходів, які безпосередньо зачіпають інтереси ділових кіл США. У Великій Британії зовнішньоекономічна політика є частиною загальної економічної політики країни. В країні практично немає міністерств, які в тій чи іншій мірі не займалися би питаннями ЗЕД. Важливу роль у сприянні зовнішньоекономічному співробітництву 
відіграють британські дипломатичні місії, які мають у своєму складі представників різних міністерств і відомств, що виконують функції торговельних радників. Рада міжнародної торгівлі сприяє координації зусиль урядових установ та ділових кіл у сфері зовнішньої торгівлі, безоплатно або за символічну плату надає допомогу компаніям в освоєнні експортних ринків. Британська національна рада з експорту застосовує оригінальну форму сприяння експорту - так звану практику відкриття «торгових вікон». При цьому британським фірмам-експортерам товарів, які намагаються вперше освоїти даний зарубіжний ринок, надається організаційно-фінансова допомога у влаштуванні виставкової експозиції. Уряд Південної Кореї в цілях надання інституційної підтримки міжнародної торгівлі та імпорту технологій заснував у 1962 р. Корпорацію сприяння торгівлі. Для стимулювання вивозу товарів і послуг був заснований День експорту, коли найкращі експортери нагороджувалися медалями та отримували народне визнання. В Японії організатором системи обслуговування зовнішньоекономічних зв'язків є держава, яка фінансує цю діяльність з бюджетних коштів. Система підтримки має розгалужений характер, охоплюючи сфери діяльності, якими є збір і аналіз маркетингової інформації, надання інформаційно-консультаційних послуг, організація рекламно-виставкової роботи, сприяння у залученні до здійснення зовнішньоекономічної діяльності нових учасників тощо. У XIX ст. уряд Росії узгоджував 3 громадськістю, промисловими і діловими колами свою зовнішньоекономічну політику, але в XX ст. цей досвід був втрачений [12].

Використовуючи закордонний досвід, у процесі реалізації експортної стратегії необхідно застосувати різні важелі стимулювання експорту, якими є:

- державне субсидування;

- пільгове кредитування і страхування експорту;

- валютна політика;

- ввезення і вивіз капіталу;

- податкові пільги експортерам, їх транспортне забезпечення;

- інформування і консультування керівництва підприємств;

- дипломатична підтримка експортерів;

- державна політика розвитку експортної бази;

- підготовка кадрів для зовнішньої торгівлі.

У 2013 р. Кабінетом Міністрів України було схвалено Концепцію створення системи державної підтримки експорту України, реалізацію якої передбачалося здійснити протягом 2013-2015 рр. Проте Концепція має суттєво декларативний характер. Їнші законодавчі та нормативноправові документи, які регламентували би функціонування в Україні інституційних, організаційних, інформаційних, фінансових умов забезпечення державної підтримки експорту, існують лише у формі проектів i не можуть слугувати правовою базою для формування системи державної підтримки експорту. В Україні не створені організаційно-правові 
умови для надання державних гарантій для підтримки експортерів в Україні.

Таким чином, Україна не має ефективної інституційної системи державної підтримки розвитку експорту.

Розвиток експортного потенціалу в Україні неможливий без фінансової підтримки з боку держави. Проте, на думку фахівців, в Україні тривалий час державна фінансова підтримка експорту розглядалася переважно як субсидування окремих галузей та виробників. Лобіювання адресних пільг, преференцій, податкових «канікул» тощо на користь наближених до влади представників великого приватного бізнесу негативно позначилися на структурі експорту та валютних надходженнях.

Дослідження процесу формування і розвитку експортного потенціалу країн світу показало, що сьогодні в реальній економіці існують два основні напрямки його розвитку: статичний, який за своїм характером базується на порівняльних національних перевагах у природно-ресурсній сфері, та динамічний, що враховує конкурентні переваги, засновані на науково-технічних досягненнях та інноваціях на всіх стадіях виробничого циклу - від створення товару до просування його до зарубіжного споживача. Більш ефективним $є$ другий підхід, однак він $\epsilon$ більш витратним.

Експортний потенціал будь-якої країни $€$ сукупністю різних елементів, які $€$ пов'язаними, взаємодоповнюючими, взаємообумовлюючими. Експортний потенціал економічної системи складається 3 експортних потенціалів іï елементів: експортний потенціал національного господарства - $з$ експортних потенціалів галузей, експортний потенціал галузі - з експортних потенціалів суб'єктів господарювання, експортний потенціал регіонів - 3 експортних потенціалів господарських одиниць певної території. Тобто основу міцного експортного потенціалу країни складають експортні потенціали конкурентоспроможних виробничих одиниць - суб'єктів господарювання.

Розглянемо найбільш перспективні, з точки зору можливостей розвитку, елементи експортного потенціалу України з врахуванням особливостей зазначених вище двох підходів.

У даний час спостерігається стійке зростання обсягів світової торгівлі послугами, що обумовлено глобалізаційними процесами, лібералізацією зовнішньоекономічної діяльності на світових ринках, компюютерізацією та розвитком інформаційних технологій. Так у 2000-2010 рр. вартість світової торгівлі послугами зросла у 3 рази. На світовому ринку послуг спостерігаються відмінності в масштабах експорту та імпорту послуг між країнами.

Так, аналізуючи цифрові показники зовнішньої торгівлі США за 2013 р., вбачається, що експорт за вказаний період склав 2 трлн 280 млрд 194 млн дол. США, 3 них товари - 1 трлн 592 млрд 784 млн дол. США, а послуги — 687 млрд 410 млн дол. США відповідно (прибл. 30 \%) [13]. Вказаний вище показник співвідношення експорту 
послуг до загального експорту є середнім для країн з високорозвиненою економікою.

Експорт послуг в Україні становить усього 17,6 \% (11 млрд 520 млндол. США) від загального обсягу експорту (65 млрд 422 млн дол. США) [14]. Цей показник є значно меншим.

Вказані відомості мають велике значення для економічного розвитку нашої держави, оскільки надання послуг є таким видом діяльності, який при своїй відносній простоті здійснення (порівняно з виробництвом товарів), а отже й низькій собівартості має доволі високу кінцеву вартість.

Також велика частка високоякісних та інноваційних послуг у валовому внутрішньому продукті держави $€$ прикметною рисою постіндустріального суспільства.

Отже, враховуючи вищевикладене, нашій державі необхідно докладати більше зусиль для здійснення прогресивного розвитку вітчизняної економіки, оскільки розмаїття на ринку суб'єктів, які все частіше надають перевагу послугам, сприяє становленню конкурентоздатного середовища, в подальшому має позитивний вплив як на якість надання таких послуг, так і на їх кінцеву вартість.

Для формування свідомого нормативно-правового інструментарію 3 метою забезпечення стабільності функціонування міжнародної торгівлі послугами, виходу на такий ринок українських підприємців вкрай важливими стають доктринальні дослідження за вказаним напрямком.

Аналізуючи чинне законодавство України, вбачається велика кількість нормативно-правових актів, які здійснюють правове регулювання експорту товарів, робіт, послуг. До основних з них можна віднести: Митний кодекс України, Закон України «Про зовнішньоекономічну діяльність», Закон України «Про єдиний митний тариф» і ін.

Проте на законодавчому рівні відсутнє нормативне закріплення терміна «експорт послуг». Частково вказану прогалину вирішує положення ст. 1 Закону України «Про зовнішньоекономічну діяльність», який визначає поняття експорту (експорту товарів), під яким розуміється продаж товарів українськими суб'єктами зовнішньоекономічної діяльності іноземним суб́'єктам господарської діяльності (у тому числі з оплатою в негрошовій формі) з вивезенням або без вивезення цих товарів через митний кордон України, включаючи реекспорт товарів. До товарів, у розумінні Закону, відноситься будь-яка продукція, послуги, роботи, права інтелектуальної власності та інші немайнові права, призначені для продажу (оплатної передачі) [15].

Для з'ясування та роз'яснення дійсного сенсу терміна «експорт послуг» необхідно використати граматичний (текстуальний) спосіб тлумачення. Отже, для встановлення розуміння поняття «експорт послуг» необхідно провести тлумачення окремих складових цього терміна, а саме «експорт» та «послуга».

Стосовно експорту необхідно звернути увагу на таке. 
3 економічної теорії випливає, що експорт (лат. exporto - виводжу) - вивезення за кордон для реалізації на зовнішніх ринках товарів, послуг і капіталу [16, с. 157].

Зміст експорту як економічного поняття визначається такими характеристиками: це вивіз за межі митної території держави; об'єктом, що фактично вивозиться, можуть бути товари, послуги, технології, капітали, інтелектуальні цінності та ін.; це вивіз без зобов'язання ввезення на територію країни-експортера. Мета такого вивезення - продаж.

За чинним законодавством України термін «експорт» використовується в якості одного з митних режимів, тобто комплексу взаємопов'язаних правових норм, що відповідно до заявленої мети переміщення товарів через митний кордон України визначають митну процедуру щодо цих товарів, їх правовий статус, умови оподаткування і обумовлюють їх використання після митного оформлення.

Так, експорт, у розумінні Митного кодексу України, це митний режим, відповідно до якого українські товари випускаються для вільного обігу за межами митної території України без зобов'язань щодо їх зворотного ввезення [17].

Ознаками митного режиму експорту є:

- об'єкт вивозу - товари;

- вивіз товарів для вільного обігу (обіг товарів здійснюється без обмежень з боку органів доходів і зборів України);

- вивіз товарів за межі митної території України;

- немає зобов'язань щодо зворотного повернення товарів.

Враховуючи вищевикладене, під експортом слід розуміти діяльність фізичних та/або юридичних осіб, що здійснюють продаж товарів, послуг, робіт та інших об'єктів цивільних прав за межі митної території України без зобов'язань щодо їх зворотного ввезення.

До ознак експорту можна віднести, зокрема, такі:

- це діяльність осіб з продажу товарів, послуг, робіт та інших об'єктів цивільних прав;

- продаж товарів, послуг, робіт та інших об'єктів цивільних прав здійснюється за межі митної території України;

- відсутність зобов'язань щодо зворотного повернення товарів, послуг, робіт та інших об’єктів цивільних прав.

Визначення сутності терміна «послуга» знаходиться в просторі наукових досліджень багатьох представників юридичної науки, що призвело до відсутності чітких критеріїв виділення вказаного поняття серед усього розмаїття об'єктів правовідносин, а в подальшому — й відсутності однакового розуміння вказаного поняття як на науковому, так і на емпіричному рівні.

Так, аналізуючи значний масив різноманітних підходів щодо визначення поняття «послуга», можливо здійснити їх класифікацію на дві великі групи. Представники першої групи (В. А. Васильєва, О.В.Дзера, 
О. С. Йоффе, Д. Іे. Степанов, Є. О. Суханов) виходять із того, що сутність послуги трактується через діяльність.

Зокрема, В. А. Васильєва, розуміла під послугою вид суспільного блага, за допомогою якого задовольняються потреби шляхом вчинення суб'єктом дій (здійснення діяльності), у корисних властивостях яких і полягає інтерес особи [18, с. 16-22].

У представників другої групи (С. С. Алексєєв, О. А. Красавчіков) послуга асоціюється з результатом. Послуга при такому визначенні набуває значення результату корисної дії або діяльності.

Не має єдності щодо вказаної категорії й у чинному законодавстві України, зокрема в актах господарського законодавства.

Частина шоста статті 139 Господарського кодексу України (далі ГК України) встановлює, що до складу товарів відносяться у тому числі й послуги. Статтею 177 ЦК України встановлено рівність категорій «товар»та «послуги» шляхом їх виділення в якості окремих об'єктів цивільних прав.

Термін «послуга» також передбачений п. 14.1.185 ст. 185 Податкового кодексу України, під якою розуміється будь-яка операція, яка відповідає таким критеріям: 1) не є постачанням товарів; 2) споживається в процесі вчинення; 3) може передбачати передачу прав на об'єкти права інтелектуальної власності та інші нематеріальні активи чи надання інших майнових прав стосовно таких об'єктів права інтелектуальної власності [19].

Окремо необхідно виділити закони України, які чітко не вказують на сутність категорії «послуга», однак встановлюють іï приналежність до товару. До таких можна віднести, зокрема, Закон України «Про зовнішньоекономічну діяльність».

Окремо необхідно звернути увагу на визначення терміна «послуга» у міжнародному приватному праві.

Так, базисом регулювання ринку послуг у Європейському Союзі $є$ положення ст. ст. 56-62 (49-55) Договору про функціонування Європейського Союзу та Директива № 206/123/ЄС від 12 грудня 2006 р. «Про послуги на внутрішньому ринку».

Зокрема, ст. 57 Договору про функціонування Європейського Союзу встановлює визначальні ознаки поняття «послуга». Так, послуги звичайно надаються за винагороду, якщо вони не регулюються положеннями щодо вільного руху товарів, капіталів та пересування осіб [20].

Послуги включають, зокрема: 1) діяльність промислового характеру; 2) діяльність торгового характеру; 3) діяльність ремісників; 4) діяльність осіб вільних професій. За практикою Європейського суду правосуддя зміст поняття «послуги» включає туристичну, медичну, фінансову, освітню, спортивну діяльність. Крім того, в окремих справах Європейський суд також включає до послуг телекомунікаційні послуги, надання кредитів на придбання житла, продаж лотерей, діяльність агенцій з працевлаштування. 
У Генеральній угоді про торгівлю послугами (ГАТС) 1994 р., що чинна в системі Світової організації торгівлі (WTO), хоч і не міститься визначення поняття послуги, однак для цілей Угоди використовується спеціальний класифікатор, котрий містить перелік 160 видів послуг, поєднаних у 12 розділів, зокрема: ділові (46 видів); зв'язку (25); будівництва й інжинірингу (5); дистриб'юторські (5); загальноосвітні (5); 3 навколишнього середовища (4); фінансові, включаючи страхування (17); 3 охорони здоров'я та соціальні (4); організація дозвілля, культури та спорту (5); транспорт (33); інші послуги. Вказаний перелік послуг багато в чому грунтується на списку, складеному ООН під назвою «Класифікація основних продуктів (послуг)» [21, с. 209].

За класифікацією $М В Ф$, послуги поділяються на три категорії: транспортні послуги, поїздки, інші послуги [22, р. 81]. До статті інші послуги входять дев'ять категорій: послуги зв'язку, послуги з будівництва, страхові послуги, фінансові послуги, комп'ютерні та інформаційні послуги, роялті та ліцензійні платежі, інші ділові послуги, послуги приватним особам, в галузі культури та відпочинку, державні послуги, що не віднесені до інших категорій [23, р.94].

Аналізуючи вищевказані погляди, можна зазначити, що якщо при розгляді послуги як виду діяльності не враховувати результат такої діяльності, як складову послуги, то виходить, що з економічної точки зору будь-яку корисну діяльність однієї особи для іншої особи, незалежно від характеру результату цієї діяльності, можна називати послугою. До такого висновку можна також дійти, якщо виявляти специфіку послуги тільки через її економічний результат, який у тому або іншому ступені може бути відокремлений від самої діяльності і на який може претендувати замовник.

Однак у випадку, якщо послугу розглядати як економічну категорію, а саме у призмі єдності процесу праці та його результату, вбачається, що під послугою слід розуміти певний вид суспільних відносин, економічна сутність яких полягає в наданні послуг, а саме здійсненні дій (діяльності), що спрямовані на створення або зміну стану блага. При цьому об'єктом цих відносин $є$ певне благо, що досягається в результаті здійснення таких дій (діяльності) і має властивості товару [24].

До визначених ознак послуги як загальноправової категорії слід віднести:

- діяльність особи, яка надає послугу;

- наявність результату діяльності, його невід’ $є$ мність від самої діяльності;

- корисний ефект послуги споживається у процесі іï надання;

- надання послуг не має уречевленого характеру.

Повертаючись до визначення сутності терміна «експорт послуг», необхідно зазначити, що йому належать усі перелічені вище ознаки експорту, з урахуванням особливостей, притаманних інституту послуг. 
Так, враховуючи той факт, що відповідно до положень п. 27 ч. 1 ст. 4 Митного кодексу України у переліку речей, що входять до складу товарів, відсутні послуги, вбачається, що норми митного законодавства не розповсюджуються на процедуру експорту послуг, а отже вимога щодо обов'язковості вивозу товарів за межі митної території України не є визначальною для останньої.

Отже, експорту послуг характерна наявність, зокрема, таких ознак:

- це діяльність осіб з продажу специфічного об’єкта - надання послуг;

- надання послуг може здійснюватися як за межі митної території України, так і в іï межах (вказана вимога не порушує приписи ЗУ «Про зовнішньоекономічну діяльність»).

Експертами та науковцями визначено особливості світового ринку послуг [25]. На наш погляд, до основних характеристик сучасного ринку послуг, що повинні бути враховані в процесі розвитку експортного потенціалу України, слід віднести такі:

- системність розвитку ринку послуг як складної системи;

- чутливість до коливання ринкової кон'юнктури;

- висока швидкість обороту капіталу, що обумовлено коротким циклом у виробництві послуг;

- постійне розширення асортименту послуг, наприклад, спостерігається підвищення попиту на спеціалізовані послуги (проектно-конструкторські, будівничо-монтажні, розробка програмного забезпечення, ноу-хау, лізингові послуги тощо);

- згідно з експертними оцінками [26], 50-80 \% приросту послуг у розвинених країнах обумовлюється попитом виробників;

- обсяги міжнародної торгівлі послугами занижені на 40-50\%. Вартість деяких послуг (наприклад, посередницькі, туристичні) визначити досить складно. Крім того, послуги часто надаються в комплексі 3 товарами, відповідно вартість послуги знаходить відображення у кінцевій вартості товару. Значна кількість міжнародних послуг, що надаються підрозділами різних фірм, не враховується в платіжному балансі;

— міжнародний обмін послугами більшою мірою, ніж торгівля продукцією, є захищеним державою, монополізованим та диференційованим.

На світовому ринку послуг $2 / 3$ світового експорту послуг припадає на США, Велику Британію, Францію, Німеччину, Японію, Бельгію, Нідерланди, І̇талію. На першу п'ятірку припадає відповідно більше 50 \% експорту. При цьому на чотири країни (США, Велика Британія, Німеччина, Франція) припадає $44 \%$ усього світового експорту послуг. На жаль, Україна є незначним гравцем на світовому ринку послуг.

Серед складових експортного потенціалу країни $€$ елемент, який самостійно здійснює експортну діяльність та одночасно $є$ передумовою реалізації експортних можливостей інших економічних суб'єктів. Таким елементом є транспорт загального користування. Найбільш суттєву 
частку в структурі міжнародної торгівлі послугами мають саме транспортні та туристичні послуги.

Експорт транспортних послуг - це численна та різноманітна сукупність послуг, що визначаються відповідним класифікатором. Експорт згрупований за видами магістрального транспорту з виокремленням вантажних і пасажирських перевезень та приведенням усіх доходних надходжень від експорту послуг до однієї розрахункової валюти - дол. США [27, с. 9].

Під експортом транспортних послуг слід розуміти надання міжнародних транспортних послуг національними транспортними підприємствами в процесі перетинання вантажем (пасажиром) державного кордону або перевезення (обробку) вантажів іноземних вантажовласників.

Зростання експорту транспортних послуг обумовлює необхідність розвивати та модернізувати транспортну інфраструктуру на основі використання найновіших технологій та впроваджених стандартів якості перевезення вантажів і пасажирів. Експорт транспортних послуг найбільш яскраво відображає ступінь розвитку економіки у різних за рівнем розвитку країнах. Вигідне геополітичне положення України, значні резерви пропускної спроможності транспортних підприємств визначають високий рівень експортного потенціалу транспортних послуг. Одночасно існують техніко-технологічні, фінансово-економічні та інші проблеми, що обмежують експортні можливості транспортної системи України. Частка транспортних послуг на душу населення в Україні у 3-4 рази менше, ніж у Німеччині та Франції, і у 15-17 разів менше, ніж у Голландії та Данії.

У процесі формування ринкової економіки фінансування транспортного сектора економіки України відбувалося на рівні, який не перевищував 20-25\% від мінімально потрібного обсягу. Така ситуація негативно вплинула на розвиток транспортної інфраструктури та модернізацію рухомого складу для впровадження нових технологій та підвищення якості транспортного обслуговування зовнішньоекономічних потоків на рівні світових стандартів. Внаслідок реалізації такої техніко-технологічної політики останнім часом стан функціонування та перспективи розвитку транспортної системи суттєво погіршилися, що створює загрозу економічній безпеці держави. Україна погіршує конкурентні позиції на міжнародних ринках, зокрема в секторах надання транспортних послуг. Основними причинами такого стану транспорту України $є$ старіння основних фондів, недостатні темпи інтеграції транспортно-дорожнього комплексу в європейську та світову транспортні системи, повільне вдосконалення транспортних технологій та недостатня їх пов'язаність із виробничими, торговельними, складськими та митними технологіями, низька ефективність фінансово-економічних механізмів, що стимулюють інвестиції у розвиток транспорту, проблеми реалізації державних і галузевих програм у галузі окремих видів транспорту.

Розглянемо окремі актуальні проблеми, пов'язані із удосконаленням та застосуванням національного транспортного законодавства. 
Стимулювання зовнішньоекономічної активності суб'єктів господарювання України сьогодні не можна здійснити без усунення формальних перешкод до вільного товарообігу та інфраструктурних вад, які заважають залучатися вітчизняним економічним суб'єктам до глобальних економічних відносин. Вітчизняне законодавство, на жаль, сьогодні містить досить багато обмежень, які не лише не відповідають публічним інтересам, але й прямо суперечать їм, адже зменшують зацікавленість інвесторів у капіталовкладеннях в українську економіку та знижують товарообіг національних господарюючих систем. Вітчизняні вимоги до суб'єктів господарювання подекуди є більшими, ніж у провідних економіках світу. Подекуди ці вимоги неможливо виконати, що відвертає від України економічних суб'єктів, зокрема транспортні потоки.

На одну із таких проблем вказав автор проекту Закону України «Про внесення змін до законодавчих актів України» (щодо ізольованого баласту) (реєстр. № 1504 від 17 грудня 2014 р.). Йшлося про необхідність вдосконалення порядку використання ізольованого баласту судновласниками у морських портах України з метою приведення законодавства України у відповідність до вимог Міжнародної конвенції по запобіганню забрудненню з суден 1973 р. (МАРПОЛ 73/78) для удосконалення процедур контролю суден з метою забезпечення безпеки мореплавства, ліквідації необгрунтованих контрольних процедур, пов'язаних із міжнародним торговельним мореплавством в українських водах. Адже чинні Правила охорони внутрішніх морських вод і територіального моря України від забруднення та засмічення, затверджені постановою Уряду від 29 лютого 1996 р. № 269 (далі - Правила), необгрунтовано відносять до скидання забруднюючих речовин злив ізольованого водяного баласту з суден в акваторіях морських портів. Це не тільки не має належного екологічного обгрунтування, але й не відповідає міжнародним договорам України в галузі торговельного мореплавства та європейській практиці.

Відповідно до вимог Міжнародної конвенції по запобіганню забрудненню з суден 1973 р. (МАРПОЛ 73/78), до якої Україна приєдналася постановою Кабінету Міністрів України від 21 вересня 1993 р. № 771, використання суднами ізольованого водяного баласту $є$ максимально ефективним засобом запобігання забрудненню морського середовища, оскільки повністю виключає (в силу повної автономності відповідних систем судна) привнесення до нього будь-яких забруднюючих речовин (нафти або рідких хімічних речовин, суднового палива та мастил, забруднених вод машинних та помпових відділень, стічних вод, інших суднових відходів). Судновласники несуть величезні додаткові витрати при оснащенні вантажних суден танками для зберігання ізольованого водяного баласту та відповідними системами для його перекачування, що надає можливість його безперешкодного та безпечного скидання у більшості морських портів світу (крім українських). Показники забрудненості ізольованого водяного баласту, як правило, є значно меншими, ніж фонові показники забруднюючих речовин в акваторіях портів. 
На часі стоїть спрощення процедур відбору та аналізу проб баластних вод суден під час контролю з боку контролюючих органів у пунктах пропуску через державний кордон України в морських торговельних портах. Потрібно прискорити обслуговування суден у морських портах та зменшити необгрунтовані витрати судновласників на штрафні санкції за дії, за які вони не відповідають у силу міжнародно-правових вимог та морської практики.

У тому числі слід на підставі зарубіжного досвіду та Міжнародної конвенції по запобіганню забрудненню з суден 1973 р. повернути процеси використання баластних вод суднами у межах вимог, що звичайно ставляться, це покращити привабливість українських морських торговельних портів. Наприклад, такі країни, як Канада, США, Австралія, Іззраїль, регламентують чіткі вимоги щодо зміни баласту у територіальних водах, які попереджали б заміну баластних вод у територіальних водах як одну з умов отримання дозволу на скид баластних вод у портових зонах. При наявності документів, підтверджуючих зміну баласту, контролюючий інспектор не має права вимагати аналіз баласту, обмежуючись лише документальною перевіркою.

Натомість законопроект 1504 було відкликано, мабуть, з огляду на його законодавчі вади. Крім тих, що були окреслені Головним науковоекспертним управлінням Верховної Ради України, слід вказати також на таке.

Незважаючи на запровадження певної ясності у питання скидання баластних вод суден, законом можна буде повністю вирішити питання підзаконного врегулювання питань контролю за скиданням баластних вод лише після запровадження чітких обмежуючих регуляторів для підвідомчої нормотворчості та підзаконного правозастосування.

Зокрема, запропоновані зміни не зможуть повною мірою виправити ситуацію із невідповідністю Правил охорони внутрішніх морських вод і територіального моря України від забруднення та засмічення, затверджених постановою Уряду від 29 лютого 1996 р. № 269, іншим положенням чинного законодавства стосовно гранично допустимих концентрацій забруднюючих речовин у внутрішніх морських водах та територіальному морі України, їх застосування для вод, які скидаються з суден.

Автор законопроекту вірно зазначав на непропорційність відповідних вимог нормативів, що наведені в додатку до Правил та передбачені для промислових ділянок рибогосподарських об'єктів. Разом з тим положення запропонованого законопроекту не можуть вплинути на ці вимоги, крім випадків, коли відповідні вимоги будуть визначені у законі, принаймні у контексті визначення граничних допустимих нормативів у взаємозв'язку із якісними показниками внутрішніх морських вод $і$ територіального моря України.

Отже, з метою більш правильного виправлення ситуації у цій сфері, необхідно ст. 67 Водного кодексу України доповнити новою частиною такого змісту: "Центральний орган виконавчої влади, що реалізує 
державну політику із здійснення державного нагляду (контролю) у сфері охорони навколищнього природного середовища, ращіонального використання, відтворення $i$ охорони природних ресурсів, у сфері охорони навколищнього природного середовища не може вводити та застосовувати вимоги щодо ізольованого баласту, які перевищують якісні показники внутрішніх морських вод у морському торговельному порту України, де відбувається відповідний аналіз».

Лише за такого формулювання Закону можуть бути поставлені перешкоди на шляху підзаконного уведення таких вимог до ізольованого баласту, який неможливо виконати в умовах судноплавства у внутрішніх морських водах України.

Не можна не звернути увагу на проблему, пов'язану із правовим забезпеченням транспортно-транзитних можливостей економіки України.

Сьогодні особливо гостро стоять перед Україною питання використання усього розмаїття потенціалів географічного, демографічного, економічного та геополітичного характеру для досягнення конкурентних переваг на ринках товарів та послуг й збільшення можливостей для економічного зростання. Не виключенням $€$ й питання використання транзитного потенціалу країни для побудови перспективних транспортних коридорів, позаяк географічне положення України на кордоні Європи та Азії цьому достеменно сприяє.

Розвиток національної транспортної галузі у цьому контексті $є$ стимулом для оновлення вітчизняних доріг, залізничних колій, транспортних розв'язок, готельного бізнесу, сервісної інфраструктури тощо. Заважають цьому розвитку недостатня повнота і стабільність української нормативної бази, фінансово-економічна криза в країні, коли питання розвитку межує з питанням виживання цілих галузей економіки. В цих умовах підтримка пріоритетних галузей економіки, ключових для розвитку всієї економічної системи, повинна стати об'єктом первинної уваги з боку держави. До традиційних правових проблем тут додається новий виклик, що зумовлений глобалізаційними процесами та фінансовою кризою. Саме тому необхідно спрямувати зусилля на пошук найоптимальніших шляхів посилення транспортно-транзитних можливостей економіки України, зокрема, й шляхом створення умов для транспортних коридорів.

На жаль, використанню транзитного потенціалу України поки що не приділяється владою належної уваги. Не вистачає й економіко-правових досліджень, що сприяли б виробленню суспільного розуміння відповідної значимості та подальших напрямів соціально-економічного розвитку у цій сфері.

Одне із небагатьох виключень у цій сфері - кандидатська дисертація Міщенко Анастасії Володимирівни «Транспортний коридор як форма правового регулювання ринку транспортних послуг в Україні», що була захищена у 2009 р. на здобуття наукового ступеня кандидата юридичних 
наук за спеціальністю 12.00.04 - господарське право, господарськопроцесуальне право.

Але цього явно недостатньо. Необхідно підвищити ефективність комплексних господарсько-правових досліджень у цій сфері, їх цінність 3 точки зору аналізу як правових, так і економічних, управлінських, фінансових, геополітичних та інших чинників розвитку економіки.

Вирішення питання стимулювання транспортної галузі і транзитних перевезень дозволило б грунтовніше зупинитися на багатьох проблемах інвестування в українську економіку, зокрема іноземного.

$\mathrm{y}$ цій царини залишається досі невирішеною низка проблем:

1. Необхідно послідовно та чітко розмежувати транспортний коридор як форму правового регулювання, як спеціальний режим господарювання, як сегмент ринку транспортних послуг та сукупність правових режимів.

Особливо в цій частині не можна погодитися із пропозицією А. В. Міщенко розуміти транспортний коридор через категорію організаційно-правової форми, ототожнюючи цей коридор із поняттям організації - суб’єкта права [28, с. 80-81]. Дійсно, термін «організація» може мати кілька значень. Це і процес, і результат, і форма, i, нарешті, окремий вид суб'єкта права. Зокрема, з позиції господарського права господарські організації є досить стійким поняттям, яким характеризуються особи, наділені господарською правосуб'єктністю. Якщо транспортний коридор наділяється правосуб'єктністю, то яким чином можуть здійснювати діяльність в цьому коридорі інші утворення. Розуміння транспортного коридору як організації, наділеної правами та обов'язками, передбачає адміністративне підпорядкування усіх учасників цього коридору певній владній верхівці, що неможливо уявити в структурі сегмента сучасного ринку, вільного входу та виходу на цей ринок. Оскільки ми не можемо транспортний коридор обнести дротом та регулювати ці відносини владно. Навіть за відсутності будь-якого правового регулювання - згадати стародавній Великий шовковий шлях транспортні коридори існують та розвиваються. Отже, доступ осіб на цю територію завжди буде вільним, непідвладним організаційній єдності. Тому організацію транспортного коридору як діяльність (цілком очевидно потребуючу державного врегулювання) не можна наділяти характеристиками суб'єкта права.

2. Не можна перебільшувати значення держави як організатора ринкових відносин, зокрема, з точки зору утворення транспортних коридорів. Транспортний коридор не буде існувати там, де $\epsilon$ лише бажання держави. Але ж навіть гіпотетично неможливо завчасно визначити учасників діяльності в межах транспортного коридору, до того ж припинення діяльності одних членів не може означати припинення самого транспортного коридору. Отже, може виникнути ситуація, коли неприбуткова організація транспортного коридору буде лише на папері. В цьому сенсі варто говорити про те, що транспортний коридор - це певна система 
відносин, умови для підвищення ефективності функціонування якої має створювати держава.

3. Потрібно активніше залучати юристів, особливо господарського профілю, у розробку механізмів розвитку транзитних потужностей України. Одними економічними знаннями тут не обійтися. По-перше, поза юридичного супроводу економісти не зможуть належно сформулювати положення законодавчих актів, виходячи із необхідності надання економічним засобам належної правової форми. Власне зміст робіт юристівгосподарників доводить, що економічні рішення (зокрема, щодо утворення транспортних коридорів) цілком можуть та мають бути досліджені юристами. По-друге, юристи-господарники запропонували багато новел, що стають на сторожі прав підприємців, зокрема, у сфері обмеження адміністративно-господарських санкцій, встановлення істотних умов договорів та їх форми, визначення принципів господарювання тощо. Не випадково слоганом Їнституту економіко-правових досліджень НАН України - провідного центру господарського права є: «Економіці - правове забезпечення, праву - економічну обгрунтованість». Отже, необхідно вести мову про пошук економічної обумовленості правових рішень, а не про розмежування економічного та юридичного елемента правотворчості.

4. Сьогодні на часі стоїть розробка Транспортного кодексу. А. В. Міщенко навіть запропонувала його приблизну структуру [28, с. 53-54]. Але треба враховувати, що розробка кодексу - це процес систематизації законодавства. Це означає не лише доопрацювання багатьох законодавчих актів із транспортних питань, але й широке скасування чинних актів транспортного права із включенням їх у єдиний кодекс, особливо, якщо це стосується дублюючих положень, застарілих чи неефективних положень. Їнакше перетворення Закону «Про транспорт»на кодекс не має сенсу.

5. Потрібно повернутися до активного стимулювання побудови західно орієнтованих транспортних коридорів (на кшталт проекту сухопутного мосту Гданськ - Одеса). А для цього потрібно забезпечити розроблення та неухильне дотримання стратегії розвитку економіки України у цій сфері, без чого законодавчі новели - це будуть лише нові нормативні обтяження, лише нормативне «ярмо»на шляху розвитку бізнесу.

У цьому контексті маємо говорити саме про активну участь держави в створенні елементів ринкової інфраструктури, що дозволять реалізувати амбітні економічні плани, у тому числі із використанням елементів державно-приватного партнерства.

Причому реалізація таких пропозицій наштовхується на нестабільність ринкового планування в Україні. Йдеться не лише про політичну нестабільність, яку усунути правовими засобами неможливо. Необхідно вдосконалити й відповідні наукові підходи.

Наприклад, у дисертації Усатого Віталія Олександровича на тему «Господарсько-правове забезпечення державної промислової політики 
України» висновки грунтуються на визначенні ролі програм економічного розвитку щодо змісту промислової політики держави [29, с. 27-32]. Разом із тим без відповіді залишається запитання про забезпечення виконуваності відповідних програм. Після 2003 р. не приймалося жодного дієвого акта щодо програмування та планування у сфері транспорту. Чи не тому це сталося, що уряди України не виконували й сьогодні не збираються виконувати положення програмних документів. Фактично це перетворює програмування та декларативне описування проблем без шансу до системного їх вирішення, прикриває політичні PR-ходи політиків, але не містять жодних зобов'язань.

Представники одеської школи господарського права (зокрема, İ. П. Поповська) [30] запропонували вирішити цю проблему закріпленням у законодавстві положення про те, що органи державної влади та місцевого самоврядування повинні відшкодувати шкоду, завдану невиконанням чи відмовою від виконання планів та державних програм економічного розвитку. Це може стимулювати до належного виконання планів, а отже, сприяти реалізації державної економічної політики.

Тому, якщо не визначитися у законодавстві із відповідною гарантією виконання програм соціально-економічного розвитку, складно розраховувати на практичне вирішення проблем послідовного здійснення відповідної політики щодо побудови транспортних коридорів в Україні.

Окрему проблему складає проблема належного застосування господарськими судами норм права у спорах щодо перевезення вантажів.

Спори щодо перевезення вантажів традиційно становлять значний масив господарських спорів. У докризовий період протягом кожного року господарські суди в Україні розглядали від однієї до півтори тисячі таких спорів. В основі цих спорів - переважно різне сприйняття сторонами доказової бази, що підтверджує факт правопорушення у сфері залізничних перевезень, а також розбіжність між положеннями численних актів законодавства у цій сфері, які по-різному тлумачаться сторонами.

Масштабність залізничних перевезень обумовлює те, що юридичні конфлікти у цій сфері транспортного обслуговування $є$ найбільш поширеними. Хоча Статут залізниць України діє з 1998 р., а Правила перевезень вантажів - з 2002 р. та, як правило, не відрізняються в основних засадах від правил, що діяли за часів СРСР, це ще не означає стабільності у застосуванні іх положень - змінюються не лише законодавчі акти вищої юридичної сили, а й економічні умови залізничних перевезень. Це обумовлює виникнення проблем у практиці розгляду судами справ про перевезення вантажів залізничним транспортом.

Перша одвічна проблема - вибір закону, який регулює відносини 3 перевезення вантажів залізницею, та тлумачення співвідношення положень підзаконних актів, з одного боку, та положень Цивільного та Господарського кодексів України - $з$ другого.

На жаль, при прийнятті Цивільного та Господарського кодексів не було чітко розмежовано законне та підзаконне регулювання відносин 
щодо перевезення вантажів. Регулювання перевізних відносин у кодексах отримало рамковий та вибірковий характер, що не дає змогу системно вирішити усі питання відносин перевезення. Ускладнює цю ситуацію ще й те, що положення ЦК та ГК України містять норми, загальні для всіх видів транспорту, позаяк автомобільний, річковий, морський, залізничний, трубопровідний та повітряний види транспорту підпорядковуються у своїй діяльності самостійним спеціальним законам (кодексам) та, що найскладніше, розгалуженим підзаконним актам.

Відсутність єдиного узагальнення у цій сфері у формі постанови Пленуму Вищого господарського суду України, попри значимість цих питань, $€$ показником складності тлумачення такої розбіжності. Разом із тим ВГСУ зробив перший крок на шляху такого тлумачення, надіславши господарським судам оглядовий лист від 21 травня 2014 р. № 0106/662/ 2014 «Про деякі питання практики застосування господарськими судами законодавства про залізничні перевезення (за матеріалами справ, розглянутих у касаційному порядку Вищим господарським судом України).

Незважаючи на намагання господарських судів уодноманітнити розгляд спорів про перевезення, руйнівну дію на цю сферу правозастосування чинить, серед іншого, те, що Статут залізниць України 1998 р., а також Статут автомобільного транспорту 1997 р. відчутно застаріли, передусім через їх спрямованість на якомога повніше задоволення інтересів саме перевізників, а не вантажовласників, виконавців, а не замовників. У відповідних актах простежується дисбаланс у встановленні правових презумпцій, порядку доказування фактів як підстав відповідальності сторін, обмеженої відповідальності перевізника, не враховуються новітні підходи до потреб подолання монополізму та захисту слабкої сторони у господарських правовідносинах.

По суті, підзаконні акти сфери перевезень орієнтуються на радянську модель економіко-правового регулювання планового типу, за якої пріоритет має захист інтересів держави, монополістів-перевізників, забезпечення безперебійності перевезень та перевага інтересів виробника послуг над інтересами їх споживача. Загальний зміст підзаконних актів з перевезення вантажів залізничним транспортом фактично має характер неуважного ставлення до потреб пересічного суб'єкта господарювання. Цей дисбаланс особливо помітний на фоні положень ЦК та ГК України, які проголосили рівність суб'єктів господарювання, стимулювання економічної конкуренції та захист слабкої сторони за договорами, принципи розумності та справедливості. Розбіжність між логікою законодавчих актів призводить до втрати елемента «інтуїтивності» правомірної поведінки, коли часто суб'єкти господарювання припускаються помилок при виконанні договорів перевезення вантажів, неправильно тлумачать професійно орієнтовані перевізні правила, а господарські суди, формально виконуючи приписи закону, здебільшого стають на сторону перевізників, на жаль, не беруть на себе відповідальність враховувати складні категорії принципів права для відновлення цього балансу. 
Наприклад, в одній зі справ (справа № 23/208, постанова Вищого господарського суду України від 12 червня 2012 р.) господарські суди формально витлумачили порядок визначення шкоди, завданої перевізником у результаті втрати вантажу, винятково на підставі документів, виданих вантажовідправником. Справді, ч. 1 ст. 115 Статуту залізниць України передбачено, що вартість вантажу визначається на підставі загальної суми рахунка або іншого документа відправника, який підтверджує кількість і вартість відправленого вантажу.

Застосування буквальної інтерпретації положень Статуту утворює проблеми на практиці, адже в багатьох випадках вантажовідправник не $\epsilon$ власником вантажу, а лише експедитором. Він не може надати законні власні підтвердження вартості вантажу, адже експедитор не купує цей вантаж, не $є$ його власником та не ставить його на свій баланс.

У ч. 2 ст. 23 Закону України «Про залізничний транспорт» зазначено, що «за незбереження (втрату, нестачу, псування, пошкодження) прийнятого до перевезень вантажу, багажу, вантажобагажу перевізники несуть відповідальність у розмірі фактично заподіяної шкоди, якщо не доведуть, що втрата, нестача, псування, пошкодження виникли 3 не залежних від них причин». Питання доказування цієї фактичної шкоди згідно з рішеннями господарського суду, таким чином, набуло допустимого характеру, який пов'язаний не з об'єктивними, а суб'єктивними критеріями. Це відрізняється від практики доказування розміру шкоди у справах інших категорій, а тому об'єктивно спричиняє спірні ситуації, по суті, заважає формувати сприятливі для перевезення вантажів відносини між експедиторами, вантажовласниками та перевізниками.

Юридизація правозастосування у цій сфері повинна враховуватися суб'єктами господарювання.

Статут залізниць України, а також Правила перевезення вантажів містять низку докладних, техніко-юридичних стандартів оформлення документації, що посвідчує ті чи інші факти у правовідносинах між перевізником, вантажовідправником і вантажоотримувачем.

Усталені підходи для подолання таких дефектів у законодавстві у судовій практиці за рахунок, наприклад, застосування принципу розумності та справедливості, передбачених у ст. 3 ЦК України, аналогії закону чи права, на жаль, поки що не сформовані. Заважають цьому не лише правові традиції, а й відсильні норми Цивільного та Господарського кодексів: згідно з ч. 5 ст. 307 ГК України, яка кореспондується 3 ч. 4 ст. 909, ч. 1 ст. 920 ЦК України, умови перевезення вантажів окремими видами транспорту, а також відповідальність суб'єктів за цими перевезеннями визначаються транспортними статутами та іншими нормативноправовими актами.

Разом $з$ тим надмірно «жорсткі» приписи підзаконних актів у цій сфері в окремих випадках почали заперечуватися положеннями актів вищої юридичної сили. 
Зокрема, практика господарських судів та Верховного Суду України щодо застосування позовної давності у відносинах перевезення досить обнадійлива у цьому контексті, адже чітко вказує на загальний інтерпретаційний напрям вирішення подібних справ: юридична сила законів переважає юридичну силу підзаконних актів.

Як приклад наведемо справу за позовом ВАТ «Концерн Стирол» до ДП «Одеська залізниця» про стягнення збитків, заподіяних у результаті недостачі вантажу, виявленої при перевезенні.

Спочатку господарські, а згодом й Верховний Суд України (постанова Верховного Суду України від 19 квітня 2012 р. у справі № 3-22гс12) співвіднесли положення Статуту залізниць України та ГК України на користь кодифікованого закону. Справді, ч. 4 ст. 315 ГК України передбачено окремий випадок розрахунку позовної давності у разі пред’явлення претензії до перевізника: «Якщо претензію відхилено або відповідь на неї не одержано в строк, зазначений у частині третій цієї статті, заявник має право звернутися до суду протягом шести місяців з дня одержання відповіді або закінчення строку, встановленого для відповіді». Але п. «а» ст. 134 Статуту залізниць України передбачено, що претензії можуть бути заявлені з дня видачі вантажу, багажу або вантажобагажу для претензій про відшкодування за псування, пошкодження або недостачу вантажу, багажу та вантажобагажу.

Верховний Суд України обгрунтовано вказав у своєму рішенні на вищу юридичну силу ГК України, а також на те (а це чинить вагому організуючу дію), що «у прикінцевих положеннях ГК України законодавець зобов'язав Кабінет Міністрів України привести свої нормативні акти (в тому числі і Статут залізниць України, оскільки він суперечить ГК України) у відповідність до норм ГК України, а тоді вже застосовувати ці норми поряд з нормами ГК України, що Кабінетом Міністрів України зроблено не було».

Однак в аналізованій справі вирішено лише одне із багатьох проблемних питань застосування позовної давності у відносинах з перевезення вантажів.

Зокрема, проблемним залишаються питання про позовну давність у випадках, коли претензія до перевізника не пред’являлася.

Проблема полягає у тому, що положеннями ЦК України не передбачено можливість підзаконного регулювання позовної давності: «Для окремих видів вимог законом може встановлюватися спеціальна позовна давність: скорочена або більш тривала порівняно із загальною позовною давністю» (ч. 1 ст. 258 ЦК України). Саме тому виникають обгрунтовані сумніви у можливості застосування положень статей 134 та 136 Статуту залізниць України про шестимісячну позовну давність у зв'язку із урегульованістю цих положень законом. Адже згідно з положеннями ч. 3 ст. 925 ЦК України «до вимог, що випливають із договору перевезення вантажу, пошти, застосовується позовна давність в один рік з моменту, що визначається відповідно до транспортних кодексів (статутів)». Отже, 
у підзаконному порядку дозволено встановлювати лише момент, з якого починає обраховуватися позовна давність, а не саму цю давність.

Разом із тим положення ст. 925 ЦК України не можуть стосуватися вимог залізниці до вантажовідправників та вантажоодержувачів. Адже згідно зі спеціальною нормою ч. 5 ст. 315 ГК України «для пред’явлення перевізником до вантажовідправників та вантажоодержувачів позовів, що випливають $з$ перевезення, встановлюється шестимісячний строк». Отже, якщо у перевезенні вантажів беруть участь суб'єкти господарювання, на вимоги залізниць до цих суб'єктів має поширюватися шестимісячна позовна давність.

На жаль, наукових досліджень та експертних висновків щодо співвідношення законного та підзаконного регулювання у цій сфері не вистачає.

Наявна судова практика дозволяє зробити висновок, що випадки застосування Статуту залізниць України та інших підзаконних актів у цій сфері як джерел права перевезень мають тлумачитися обмежувально, відповідно до положень ЦК та ГК України, законів України «Про транспорт» та «Про залізничний транспорт». Їншими словами, підзаконні акти у цій сфері не можуть змінювати положення законів, крім випадків, коли у самому законі (кодексі) міститься дозвіл на таке застосування.

Хоча вказані вище положення ч. 5 ст. 307 ГК України та ч. 4 ст. 909, ч. 1 ст. 920 ЦК України визначають застосування статутів та інших підзаконних актів у цій сфері, це не означає, що ЦК та ГК України усуваються від регулювання відносин з перевезення у сферах дії транспортних статутів та інших підзаконних актів.

На це вказує хоча б той факт, що в багатьох наступних положеннях кодексів з окремих, але не всіх відносин перевезення також $€$ відсилання до транспортних статутів та кодексів. Така система викладення нормативно-правового регулювання вказує на те, що у випадках, коли відсилання відсутнє, пряму дію можуть мати положення ЦК або ГК України.

Наприклад, у ст. 917 ЦК України йдеться про порядок «надання транспортних засобів і пред'явлення вантажу до перевезення», а у ст. 918 - про порядок «завантаження та вивантаження вантажу». Однак якщо ст. 918 містить відсилання до транспортних кодексів (статутів), то у ст. 917 такі відсилання відсутні, отже, відповідний порядок має відповідати встановленому в ЦК України.

У ГК України закріплено підпорядкованість підзаконних актів положенням кодексу з питань перевезення. Зокрема, чітко регламентуються випадки застосування підзаконних актів для договорів перевезення вантажів. У ч. 5 ст. 306 ГК України зазначено: «Загальні умови перевезення вантажів, а також особливі умови перевезення окремих видів вантажів (вибухових речовин, зброї, отруйних, легкозаймистих, радіоактивних та інших небезпечних речовин тощо) визначаються цим Кодексом і видани- 
ми відповідно до нього транспортними кодексами, транспортними статутами та іншими нормативно-правовими актами».

У ч. 2 ст. 307 визначається обсяг підзаконного регулювання порядку та форми договору перевезення. У реченні другому ч. 4 ст. 307 ГК УКраїни встановлено можливість підзаконного врегулювання порядку укладання довгострокових договорів перевезення вантажів. Окремі питання щодо порядку розпорядження вантажем, роботи перевалочних пунктів та доставлення вантажу, презумпції вини перевізника та деякі інші дозволяється вирішувати у підзаконному порядку відповідно до ст. 309, ч. 4 ст. 310 , ч. 2 та 3 ст. 311 , ч. 1 ст. 313 , ч. 2 ст. 314 , ч. 6 ст. 315 .

У ст. 22, ч. 1 ст. 23, ст. ст. 24-26 Закону України «Про залізничний транспорт» теж обмежено випадки застосування підзаконного регулювання у цій сфері.

У ч. 2 ст. 7 Закону України «Про транспорт» зроблено загальне застереження щодо ціноутворення у підзаконному порядку: «Розрахунки із споживачами послуг транспорту загального користування проводяться на основі чинних тарифів у порядку, визначеному кодексами (статутами) окремих видів транспорту та іншими актами законодавства України».

Отже, доцільно враховувати у судовій практиці, що застосування Статуту залізниць України та інших підзаконних актів у сфері залізничних перевезень допускається у випадках, передбачених положеннями ЦК та ГК України, законів України «Про транспорт», «Про залізничний транспорт». В інших випадках договірні відносини щодо перевезення вантажів, застосування заходів відповідальності мають підпорядковуватися положенням законів (кодексів) про перевезення вантажів, у тому числі з урахуванням спеціального характеру Закону України «Про залізничний транспорт» відносно ГК України та спеціального характеру ГК України щодо положень ЦК України про перевезення.

Для обгрунтування незастосування положень підзаконних актів варто враховувати положення ст. 4 ГК України про те, що господарський суд не застосовує акти державних та інших органів, якщо ці акти не відповідають законодавству України.

Традиційно вважається, що підзаконні акти мають бути узгоджені із положеннями законів. Але складність полягає саме у кричущих особливостях перевізної діяльності у різних видах транспорту, коли загальні вимоги законів України здатні зруйнувати системність санкціонованого підзаконного регулювання. Саме у цьому разі підвищується роль судової практики, яка має визначити цей баланс особливого та засадничого.

Названі проблеми $є$ особливо актуальними для морського транспорту України як базового системоутворюючого чинника розвитку економічної системи держави. У транспортній системі України важливу роль відіграє сектор портової діяльності. Саме підприємства портової діяльності переважно $€$ зовнішньоекономічними «воротами» держави.

Рівень конкуренції залежить від ступеня свободи доступу на ринок (виходу з нього). Ступінь свободи доступу на ринки портових робіт 
і послуг значною мірою залежить від наявності дієвих нормативно-правових актів. На перший погляд, сучасні ринкові бар'єри у сфері портової діяльності $€$ мінімальними внаслідок реалізації сучасної державної політики регулювання портової діяльності в багатьох країнах. Однак в сучасних умовах портова діяльність $€$ витратною з точки зору капітальних та поточних витрат. Пропозиція портових послуг зростає повільними темпами, особливо в межах короткострокового періоду, що обумовлюється низькими темпами створення нових виробничих потужностей у сфері портової діяльності та значними витратами. Розвиток сучасних терміналів вимагає значних територій і значних інвестиційних ресурсів, що $€$ вкрай обмеженими чинниками в умовах портової діяльності України. Таким чином, численні чинники зумовили підвищення рівня інтенсивності конкуренції у сфері портової діяльності на національному та міжнародному рівнях.

За таких умов підприємства портової діяльності повинні приділяти значну увагу розробці та реалізації стратегії розвитку конкурентних переваг. У сфері обслуговування експортних вантажопотоків підприємства мають враховувати чинник мінливості структури та обсягів експортних вантажопотоків. Відповідно такі підприємства повинні мати певні резерви для змін ступеня використання та переорієнтації потужностей. Зазначене вимагає наявності певних фінансових ресурсів. Для накопичення відповідних фінансових ресурсів необхідні заходи підтримки з боку держави. В умовах обмежених можливостей держави у сфері фінансової підтримки розвитку експортних потужностей підприємств вважається за доцільне удосконалення правових засад створення економічних територій зі спеціальними умовами функціонування на території морських портів, що дозволять підвищувати їх інвестиційну привабливість для залучення коштів з метою розвитку конкурентних переваг у сфері експортної діяльності, що $є$ передумовою розвитку експортного потенціалу транспортної системи та економіки України в цілому.

3 урахуванням тенденцій на світовому ринку транспортних послуг необхідно розвивати основи для надання повного спектра логістичних послуг на основі формування логістичних центрів. При цьому транспортно-логістична сфера України знаходиться на досить низькому рівні свого розвитку в порівнянні з іншими країнами світу.

$\mathrm{V}$ цей час спостерігається слабка державна підтримка та відсутність відрегульованої законодавчої бази, яка б забезпечувала розвиток логістичних операцій в Україні. В Україні лише частково сформовані передумови розвитку провайдерів, здатних надавати комплексні логістичні послуги та здійснювати інтегроване управління логістичними ланцюгами підприємства-клієнта. Актуальним напрямком розвитку логістичних операцій $є$ оптимізація бізнес-процесів протягом усього ланцюга поставок.

Неефективною $є$ державна підтримка розвитку логістичних операцій і на морському транспорті. Державна підтримка формування логістичної мережі у морегосподарському комплексі повинна бути сконцентрована 
на забезпеченні посилення ефективної взаємодії підприємств морегосподарського комплексу, центральних і місцевих органів виконавчої влади та органів місцевого самоврядування.

Набуття Україною асоційованого членства у Європейському Союзі вимагає масштабного розвитку всіх елементів ринку транспортних послуг та поступової інтеграції його до європейського ринку послуг транспортної галузі.

Отже, актуальним виглядає й дослідження питання приведення національного транспортного законодавства до європейських стандартів відповідно до вимог Угоди про асоціацію між Україною та Європейським Союзом.

16 вересня 2014 р. Верховна Рада України ратифікувала УА шляхом прийняття відповідного закону [31]. İ хоча процес ратифікації у $Є C$ та країнах - членах $€ С$, що також $€$ членами УА, ще не завершився, деякі з положень УА вже застосовуються відповідно до положень ст. 486 УА, що передбачає тимчасове застосування іiі положень до ратифікації усіма членами та передання ратифікаційних грамот депозитарію.

У наукових джерелах зазначається про суттєве розширення сфер взаємовідносин між Україною та ЄС відповідно до УА у порівнянні $з$ Угодою про партнерство і співробітництво між Україною та ЄС від 1994 р. [32]; велике значення УА щодо наближення економічної системи України до відповідної системи країн Євросоюзу на основі взаємної лібералізації.

Г. Живора справедливо зазначає, що «УА не $є$ класичним прикладом зони вільної торгівлі, оскільки передбачатиме лібералізацію торгівлі не лише товарами, а й послугами, лібералізацію руху капіталів та робочої сили. Вона також обумовить адаптацію Україною європейського регуляторного законодавства. Це у свою чергу приведе до процесу глибокого проникнення інститутів ЄС, законодавства, норм і правил ведення бізнесу в Україні». Позиція вказаного автора підтверджує, що набрання чинності УА зумовить внесення змін до національного законодавства не лише щодо зовнішньоторговельної діяльності, пов'язаної із застосуванням заходів тарифного та нетарифного регулювання, але й діяльності щодо надання транскордонних послуг, у т.ч. транспортних.

Аналіз положень УА дозволяє дійти висновків, що остання структурно складається 3 преамбули, статті 1 «Цілі», 7 розділів (розділ I «Загальні принципи», розділ II «Політичний діалог та реформи, політична асоціація, співробітництво та конвергенція у сфері зовнішньої та безпекової політики», розділ III «Юстиція, свобода та безпека», розділ IV «Торгівля і питання, пов'язані з торгівлею», розділ V «Економічне та галузеве співробітництво», розділ VI «Фінансове співробітництво та положення щодо боротьби з шахрайством», розділ VII «Інституційні, загальні та прикінцеві положення»), а також додатків та протоколів.

Аналіз тексту УА (без врахування додатків та протоколів) дозволяє дійти висновку, що положення, які безпосереднього стосуються транс- 
порту, містяться у двох розділах так званої економічної частини УА IV та V.

До положень УА, що регулюють відносини у сфері транспорту, можна відносити:

1) положення щодо лібералізації (між членами УА) надання транспортних транскордонних послуг з використанням морського, автомобільного, залізничного, внутрішнього водного та повітряного транспорту (підрозділ 7 частини 5 глави 6 розділу IV УА);

2) положення щодо співробітництва у сфері транспорту, спрямовані на реструктуризацію та оновлення транспортного сектора України і поступову гармонізацію транспортного законодавства України із стандартами, існуючими в ЄC (глава 7 розділу V).

Викликає увагу Додаток XXXII до глави 7 розділу V УА, який містить акти законодавства ЄС та терміни, протягом яких Україна зобов'язується поступово наблизити своє законодавство до вказаних актів. Частина 1 вказаного додатку містить відповідні акти законодавства ЄС у сфері автомобільного транспорту (наприклад, Директива № 2009/40/ЄС Європейського парламенту та Ради від 6 травня 2009 р. про перевірки 3 придатності до експлуатації автомобілів та автопричепів), частина 2 у сфері залізничного транспорту (наприклад, Директива Ради № 95/18/ ЄC від 19 червня 1995 р. про ліцензування залізничних підприємств), частина 3 - у сфері авіаційного транспорту (зокрема, містяться вимоги щодо укладення та імплементації Угоди про спільний авіаційний простір між Україною та ЄС та їі державами-членами), частина 4 - у сфері морського транспорту (наприклад Директива № 2009/16/ЄС Європейського парламенту та Ради від 23 квітня 2009 р. стосовно контролю державою порту), частина $5-$ у сфері внутрішнього водного транспорту (наприклад, Директива № 2008/68/ЄС Європейського парламенту та Ради від 24 вересня 2008 р. щодо перевезення небезпечних вантажів внутрішніми шляхами).

Окремі дії щодо наближення національного законодавства у сфері транспорту до актів ЄС вже були здійснені та продовжують здійснюватись. Так, наприклад, Україна, ЄС та країни — члени ЄС здійснюють підготовчі дії щодо підписання Угоди про спільний авіаційний простір, яка спрямована на взаємне відкриття ринків та інтеграцію України у спільний європейський авіаційний простір [33]. Зокрема, Розпорядженням Президента України від 28 травня 2015 р. № 516/2015-рп уповноважено міністра інфраструктури України на підписання вказаної угоди, що повинно бути зроблено найближчим часом.

У контексті приведення національного законодавства до актів законодавства ЄC, що містяться у Додатку XXXII до УА, не можна не звернути увагу на проблему, пов'язану з тим, що деякі акти ЄC, які виступають орієнтиром для адаптації національного законодавства, вже втратили свою чинність (у т.ч. Й на підставі видання інститутами та органами ЄС оновлених актів, що регулюють відносини у відповідній сфері 
транспорту). Наприклад, вже згадувана Директива Ради № 95/18/ЄС від 19 червня 1995 р. про ліцензування залізничних підприємств, положення якої мають бути впроваджені протягом 8 років з дати набрання чинності УА, на теперішній час скасована Директивою № 2012/34/ЄС Європейського парламенту та Ради від 21 листопада 2012 р. про запровадження єдиної Європейської залізничної мережі, окремі норми якої присвячені ліцензуванню [34].

Виникає запитання: чи необхідно як взірець для адаптації транспортного законодавства використовувати ті акти ЄС, які містяться в Додатку XXXII (незважаючи на їх чинність чи нечинність на теперішній час), чи у разі, якщо відповідні акти були скасовані, використовувати нові акти, які регулюють подібні відносини, що й регулювали акти, які скасовані.

На важливість вказаної проблеми вказує й факт iï зауваження заступником голови Адміністрації Президента України Д. Шимківим, який зазначив: «До 1 січня 2016 р. необхідно визначитись - ми наближуємось до норм законодавства, які були підписані на момент укладення УА, чи оновити їх відповідно до прогресу, який має місце у ЄС. Справа в тому, що коли підписувалась УА, точкою відліку було діюче законодавство ЄС. Воно змінилось за цей час. Іे у деяких питаннях зміни достатньо змістовні. Тому є питання, які необхідно врегулювати... шляхом, можливо, змін до УА, й вони б визначали, що ми орієнтуємось на оновлене законодавство ЄС» [35]. Деякі автори розкритикували зазначену позицію з огляду на те, що будь-які зміни до УА приведуть до необхідності їх ратифікації усіма сторонами УА, що займе тривалий час та виглядає нереалістичним.

Однак аналіз УА показує можливість внесення змін до окремих положень УА та окремих додатків до неї (в яких власне й міститься перелік актів ЄС, до яких Україна має наблизити своє законодавство), у порядок, відмінний від внесення змін до міжнародного договору, шляхом прийняття рішень інституціями, що створюються на підставі УА. Наприклад, відповідно до ч. 3 ст. 211 УА підкомітет з географічних зазначень, що створюється на підставі УА, відповідає, зокрема, за внесення змін до частини А Додатка XXII-A до цієї Угоди стосовно посилань на законодавство, що застосовується на територіях сторін. У свою чергу, згідно зі ст. 326 УА, комітет з питань торгівлі може прийняти рішення про внесення змін до глави 13 УА, до Правил процедури арбітражу, зазначених у Додатку XXIV УА, та до Кодексу поведінки членів арбітражних груп та посередників, що містяться у Додатку XXV УА. Водночас можливість внесення змін до міжнародного договору суб'єктами, що не укладали цей договір, може викликати проблеми суто міжнародноправового характеру, а також національного характеру, пов'язаних із обов'язковістю ратифікації змін до міжнародного договору за законодавством відповідної держави. Залишимо цю проблему на розсуд представників міжнародного права, зазначивши, що положення УА 
не передбачають можливість внесення змін відповідними інституціями саме до тих положень, що регулюють відносини у сфері транспорту.

На нашу думку, при адаптації національного транспортного законодавства до відповідного законодавства ЄС згідно з вимогами УА національний законодавець повинен, перш за все, дотримуватись вимог діючої редакції УА та додатків до неї. Однак у разі, якщо відповідний акт $Є С$, що міститься у додатку до УА, скасований, доцільним буде вираховування положень «нового» акта ЄС, що регулює подібні відносини та здійснення впровадження у національне законодавство тих положень «нового»акта, що не суперечать та доповнюють норми акта ЄС, який скасований, однак міститься у додатках до УА як стандарт для адаптації.

Власне й дух окремих положень УА дозволяє дійти висновку про необхідність врахування змін, що можуть відбутись в законодавстві ЄС. Так, наприклад, у ст. 153 УА, що присвячена адаптації законодавства у сфері державних закупівель, зазначено, що при здійсненні адаптації «належна увага повинна приділятися... будь-яким змінам в acquis ЄC... Європейська Комісія повідомляє Україні без невиправданої затримки про будь-які зміни в асquis ЄС. Комісія надаватиме відповідні консультації й технічну допомогу з метою впровадження таких змін». У свою чергу, у ч. 2 ст. 253 термін «законодавство про конкуренцію» розглядається для $Є С$ не лише як акти $Є С$, що чинні на момент укладення УА, але й будь-які зміни, які можуть бути внесені до відповідних актів після набрання чинності УА. На жаль, відсутнє пряме зазначення про необхідність врахування змін до асquis $Є С$ при модернізації національного транспортного законодавства, однак загальна спрямованість вищевказаних та інших норм УА дозволяє дійти висновку про необхідність врахування й тих актів ЄС, що набули чи набудуть чинності після вступу в силу УА.

Таким чином, до основних положень УА, що регулюють відносини у сфері транспорту, необхідно відносити: 1) положення щодо лібералізації (між членами УА) надання транспортних транскордонних послуг з використанням морського, автомобільного, залізничного, внутрішнього водного та повітряного транспорту (підрозділ 7 частини 5 глави 6 розділу IV УA); 2) положення щодо співробітництва у сфері транспорту, спрямовані на реструктуризацію та оновлення транспортного сектора України і поступову гармонізацію транспортного законодавства України із стандартами, існуючими у ЄС (глава 7 розділу V).

При здійсненні приведення національного транспортного законодавства відповідно до стандартів ЄС Україна має враховувати як акти законодавства ЄС, на які є посилання в УА та додатках до УА, так і ті акти законодавства ЄС, що набули чинності після підписання УА.

Актуальним виглядає здійснення нових наукових досліджень, присвячених аналізу відповідності діючого транспортного законодавства України актам ЄС, що регулюють транспортні відносини у межах цього інтеграційного об’єднання. 
Україна може стати центром надання IT-аутсорсингу в Європі та вже найближчим часом мати річний оборот у цій галузі понад 1015 млрд дол. США [36]. Очікується, що у 2016 р. ІІКТ ринок отримає дохід майже в 3,7 трлн євро. Вважається, що світовий ВВП складатиме 60,7 трлн євро. Тобто частка ІІКТ у світовому ВВП дорівнюватиме майже 6,2 \% (порівняно з часткою в 5 \% у 2013 р.). Даний показник відображає стрімке зростання обсягів ринку інформаційно-комунікаційних послуг.

За попередніми оцінками, сучасний річний оборот України у цій галузі не перевищує 1,5 млрд дол. США при тому, що загальносвітовий показник сягає приблизно 288 млрд дол. США на рік. В Україні IT-аутсорсинг $€$ перспективною сферою національної економіки, основою розвитку якої $є$ високий рівень освіти. Українські вищі навчальні заклади щороку випускають до 30 тис. дипломованих фахівців ІІТ-сфери. Річний оборот України в цій галузі можна збільшити до 10-15 млрд дол. США. Для створення в країні близько 100 тис. нових робочих місць для ІТ-фахівців до 2016 р. потрібно інвестувати близько 1 млрд дол. США.

У сфері міжнародного туристичного бізнесу річний оборот становить понад 2 трлн дол. США. На туризм припадає $12 \%$ загальносвітового національного продукту та 7 \% світових інвестицій.

Якщо говорити про наявність туристичних ресурсів як основу розвитку туризму, Україна має значний туристично-рекреаційний потенціал, сприятливий клімат, багату флору й фауну, культурно-історичні пам'ятки світового рівня. Однак значна частина туристичних об'єктів потребує впорядкування та відновлення, недостатня увага приділяється збереженню довкілля. Для залучення іноземних туристів необхідно забезпечити проведення рекламно-інформаційної кампанії з використанням засобів масової інформації в Україні та за кордоном, проведення презентацій, організації мережі інформаційних центрів для іноземних туристів. Важливим фактором у розвитку ринку туристичних послуг $€$ розвиток транспортного сполучення та забезпечення необхідного рівня безпеки подорожей [37]. Серед основних причин гальмування розвитку ринку туристичних послуг слід відзначити недосконалість системи державного регулювання туристичної діяльності, високий рівень податків, низький рівень інвестицій у розвиток матеріальної бази туризму, невідповідність туристичних закладів міжнародним стандартам, недостатнє забезпечення туристичної галузі кваліфікованими спеціалістами, незадовільний стан транспортної інфраструктури, низьку поінформованість потенційних споживачів туристичного продукту. Для забезпечення дієвості ринку туристичних послуг необхідно удосконалювати існуючу законодавчу базу, розвивати фінансові стимули залучення інвестицій, здійснювати підготовку кваліфікованих спеціалістів, розвивати інфраструктуру, в тому числі транспортного забезпечення; створити та реалізувати програму із захисту довкілля та культурної спадщини; здійснювати рекламноінформаційну підтримку тощо. 
Таким чином, на сучасному етапі розвитку світової економіки експортний потенціал $є$ найважливішою характеристикою економічної потужності будь-якої країни. Питання удосконалення експортного потенціалу України залишається актуальним. Незважаючи на різке скорочення експорту в 2014 р. (на 13,5 \%), Україна все ще має потенціал розвитку з орієнтацією на зовнішні ринки. Головною метою реалізації експортної стратегії України має бути розвиток експортного потенціалу 3 подальшою переорієнтацією його на високотехнологічні галузі, а також товари з максимально високою часткою доданої вартості. Для повноцінного використання експортного потенціалу України необхідно сформувати сприятливі інституціональні (економічні, організаційні, правові та інші) умови розвитку технологій та відтворення капіталу вітчизняних експорто орієнтованих підприємств. Глобалізація світових ринків, розвиток інформаційних технологій обумовлюють зростання обсягів торгівлі послугами, появу нових видів послуг. У структурі послуг значне місце займають транспортні послуги. Україна має високий експортний потенціал транспортних послуг. Розвиток експортного потенціалу транспортної сфері неможливий без відповідного інфраструктурного забезпечення, що обумовлює розвиток логістичних операцій та відповідної фінансової підтримки з боку держави. Взаємовигідне об'єднання виробничих, наукових, інвестиційних та інших конкурентних переваг експорто орієнтованих підприємств, зокрема транспортних, дозволить підвищити експортний потенціал сучасної України.

\section{Л і т е р а т р а}

1. Быкова Н. В. Региональные особенности экспортного потенциала Украины [Електронний ресурс] / H. В. Быкова. - Режим доступу: http://fan-5.ru/na5/00528-1.php.

2. Михайлов В. С. Методичні аспекти розрахунків експортних (імпортних) цін суб'єктами зовнішньоекономічної діяльності України / В. С. Михайлов // Формування ринкових відносин в Україні : зб. наук. пр. / НДЕї Мінекономіки. — 2004. — № 5 (36). С. $68-72$.

3. Кулинич Р. О. Аналіз зовнішньоторгівельної діяльності як один із чинників формування обсягу ВВП України [Електронний ресурс] / P. О. Кулинич. - Режим доступу: http://www.univ.km.ua/visnyk/477.pdf.

4. Экономическая энциклопедия / под ред. Л. И. Абалкина; Ин-т экономики Рос. акад. наук. - М. : Экономика, 1999. - 432 с

5. Манов 3. О. Региональная экономика [Електронний ресурс] / 3. О. Манов. - Режим доступу: http://uchebnikionline.com/rps/regionalna_ekonomika_-_maniv_zo/ eksportniy_potentsial_ukrayini_mozhlivosti_yogo_realizatsiyi_svitovomu_rinku.htm.

6. Дерев'янко О. В. Експортна стратегія України за умов глобалізації світового ринку автореф. дис. ... канд. екон. наук : 08.02.03 [Електронний ресурс] / О. В. Дерев’янко ; Київ. нац. ун-т ім. Т. Шевченка. - К., 2001. - 20 с.

7. Коврига А. В. Институциональное предпринимательство в экономике Украины: к вопросу теоретико-методологического обеспечения / A. B. Коврига // Соціальні пріоритети в транзитивній економіці : зб. наук. пр. / за ред. Г. В. Задорожного, О. М. Василева, Г. С. Волинського [та ін.]. - Х., 1999. - С. 211-220. 
8. Сизякина М. С. Асимметричность институциональной и технологической структур экономики : автореф. дис. ... канд. экон. наук: 08.00.00 / М. С. Сизякина. - Ростов н/Д, 2010. - 20 с.

9. Норт Д. Институты, институциональные изменения и функционирование экономики / Дуглас Hорт ; [пер. с англ. А. Н. Нестеренко ; предисл. и науч. ред. Б. З. Мильнера]. - М. : Фонд экон. кн. «Начала», 1997. - 634 с.

10. По итогам 2014 года экспорт украины потерял 9 млрд долларов [Електронний ресурс]. - Режим доступу: http://ubr.ua/finances/macroeconomics-ukraine/po-itogam2014-goda-eksport-ukrainy-poterial-9-mlrd-dollarov-323605.

11. Посол Пайетт оценил экспортный потенциал Украины в торговле с США [Електронний ресурс]. - Режим доступу: http://glavnoe.ua/news/n222226.

12. Стимулирование экспортной деятельности в зарубежных странах и практика поддержки экспорта в России [Електронний ресурс]. - Режим доступу: http://www.iep.ru/ files/text/usaid/Eksp-dejat.pdf.

13. Внешняя торговля [экспорт, импорт] США за 2013 год [Електроний доступ] // Офіційний сайт Їнформаційного центру світової економіки. - Режим доступу: http:// weic.info/ekonomicheskie_stati/vneshiaia_torgovlia_import_eksport_ssha_i_ee_ struktura_za_2013_god.

14. Експорт-імпорт послуг за країнами світу за 2014 рік [Електронний доступ] // Офіційний сайт Державної служби статистики України. - Режим доступу: http:// www.ukrstat.gov.ua.

15. Про зовнішньоекономічну діяльність: Закон України від 16 квіт. 1991 р. № 959-ХII (із змін. та доп.) // Відомості Верховної ради УРСР. - 1991. - № 29. - Ст. 377.

16. Борисов А. Б. Большой экономический словарь / А. Б. Борисов. - М. : Кн. мир, 2003. - 895 с.

17. Митний кодекс України від 13.03.2012 № 4495-VI (із змін. та доп.) // Відомості Верховної ради України. - 2012. - № 44-48. - Ст. 552.

18. Васильєва В. А. Цивільно-правове регулювання діяльності з надання посередницьких послуг : монографія / B. А. Васильєва. - Ївано-Франківськ : ВДВ ЦїП Прикарпат. нац. ун-ту ім. Василя Стефаника, 2006. - 356 с.

19. Податковий кодекс України від 02.12.2010 № 2755-VI (із змін. та доп.) // Відомості Верховної ради України. - 2011. - № 13-17. - Ст. 112.

20. Договор о функционировании Европейского Союза [Електронний ресурс] // Сайт Права Європейського Союзу. - Режим доступу: http://eulaw.ru/treaties/tfeu.

21. Вельяминов Г. М. Международное экономическое право и процесс (академический курс) / Г. М. Вельяминов. - М. : Волтерс Клувер, 2004. - 732 с.

22. Balance of Payment Compilation Guide. International Monetary Fund. - Washington, 1995. - $407 \mathrm{p}$.

23. Balance of Payments Textbook. International Monetary Fund. - Washington, DC, USA, 1996. - $150 \mathrm{p}$.

24. Шульга Р. Р. Категорія «Торгівля послугами»: сутність та проблеми застосування у господарському законодавстві України [Електронний ресурс] / P. Р. Шульга // Форум права. - 2010. - № 4. - C. 976-980. - Режим доступу: http:// www.nbuv.gov.ua/ejournals/FP/2010-4/10sppgzu.pdf.

25. Лунько М. Е. Факторы и особенности развития мирового рынка услуг [Електронний ресурс] / М. Е. Лунько // НоваИнфо. - 2014. - № 24. - Режим доступу: http:/ /novainfo.ru/archive/24/razvitie-mirovogo-rynka-uslug.

26. Соколова Ю. В. Світовий ринок послуг [Електронний ресурс] / Ю. В. Соколова // Економічні науки. - 2007. - Режим доступу: http://rusnauka.com/21_NIEK_2007/ Economics/24804.doc.htm.

27. Ковзель М. О. Соціально-економічна ефективність експорту транспортних послуг України : автореф. дис. ... канд. екон. наук: 08.00.03 / М. О. Ковзель; Укр. держ. акад. заліз. трансп. - Х., 2008. - 20 с. 
28. Мішенко А. В. Транспортний коридор як форма правового регулювання ринку транспортних послуг в Україні : дис. ... канд. юрид. наук : 12.00.04 / A. В. Мішенко ; Нац. юрид. акад. України ім. Ярослава Мудрого. - Х., 2009. - 205 с.

29. Усатий В. О. Господарсько-правове забезпечення державної промислової політики України : дис. ... канд. юрид. наук : 12.00 .04 / В. О. Усатий ; Нац. юрид. ун-т ім. Я. Мудрого. - Х., 2014. - 230 с.

30. Поповська Іे. П. Правові основи програмного регулювання господарської діяльності в Україні : дис. ... канд. юрид. наук : 12.00.04 / І П. П. Поповська; Одес. нац. юрид. акад. - O., 2010. - 212 с.

31. Про ратифікацію Угоди про асоціацію між Україною, з однієї сторони, та Європейським Союзом, Європейським співтовариством з атомної енергії і їніми державамичленами, з іншої сторони : Закон України від 16 верес. 2014 р. № 1678-VI (із змін. та доп.) // Відомості Верховної ради України. - 2014. - № 40. - Ст. 2021.

32. Угода про партнерство і співробітництво між Україною і Європейськими Співтовариствами та ї державами-членами : міжнар. док. від 14 черв. 1994 р. // Офіційний вісник України. - 2006. - № 24. - Ст. 1794.

33. Україна парафувала з ЄС Угоду про спільний авіаційний простір [Електронний доступ] // Офіційний сайт Кабінету Міністрів України. - Режим доступу: http:// www.kmu.gov.ua/control/uk/publish/article?art_id=246883289\&cat_id=244276429.

34. Директива № 2012/34/ЄС Європейського Парламенту та Ради від 2листопада 2012 р. «Про запровадження Єдиної залізничної мережі» [Електронний доступ] // Офіційний сайт компанії «Консультант Плюс». - Режим доступу: http:// www.consultant.ru/document/cons_doc_INT_29573.

35. В угоді про асоціацію з ЄС можливі технічні зміни - Шимків [Електронний доступ] // Офіційний сайт інтернет-холдингу «Українська правда». - Режим доступу: http:/ /www.pravda.com.ua/news/2015/05/16/7068118/?attempt=1м ; http:// www.ukrinform.ua/ukr/news/pislya_smuti_ukraiina_moge_stati_liderom_na svitovomu_rinku_it_poslug_1934472.

36. Ладиченко К. І. С̆ Счасні тенденції розвитку світового ринку інформаційно-комунікаційних послуг [Електронний ресурс] / K. I. Ладиченко // Ефективна економіка: електроне фахове видання. - Режим доступу: http://www.economy.nayka.com.ua/ ? $\mathrm{p}=1 \& \mathrm{z}=3830 \& \mathrm{p}=1$.

37. Джаман М. О. Розвиток ринку туристичних послуг в Україні / М. О. Джаман, T. О. Гусаковська // Науковий вісник Полтавського університету економіки і торгівлі. - 2011. - № 5 (50). - С. 20-23.

\section{А н о т а ція}

Кібік О.М., Подцерковний О. П., Котлубай В.О., Хаймінова Ю. В., Драпайло Ю. З., Постоленко Ю. П., Брагарник О.О., Козолуп М. С. Організаційно-правові передумови інтенсифікації експортної діяльності в Україні. - Стаття.

Стаття присвячена дослідженню проблем розвитку експортного потенціалу України та обгрунтуванню основних організаційно-правових чинників підвищення ефективності експортної діяльності країни з урахуванням найбільш перспективних елементів іiі експортного потенціалу.

Ключові слова: експортний потенціал, експортна діяльність, експорто орієнтовані підприємства, організаційно-правові передумови. 
О. М. Кібік та ін. Передумови інтенсифікації експортної діяльності в Україні 105

\section{А н нот а ция}

Кибик О. Н., Подцеерковный О. П., Котлубай В. А., Хайминова Ю.В., Драпайло Ю. З., Постоленко Ю. П., Брагарник О. А., Козолуп Н. С. Организационно-правовые предпосылки интенсификации экспортной деятельности в Украине. - Статья.

Статья посвящена исследованию проблем развития экспортного потенциала Украины и обоснованию основных организационно-правовых факторов повышения эффективности экспортной деятельности государства, учитывая наиболее перспективные элементы ее экспортного потенциала.

Ключевые слова: экспортный потенциал, экспортная деятельность, экспорто ориентированные предприятия, организационно-правовые предпосылки.

\section{S u m m a r y}

Kibik O., Podtserkovniy O., Kotlubay V., Khayminova U., Drapaylo Y., Postolenko U., Bragarnik O., Kozolup M. The organizational and legal conditions of intensification of the export activity in Ukraine. - Article.

The article is devoted to the problems of development of export potential of Ukraine and substantiation of basic organizational and legal conditions increasing the efficiency of export of the country on the basis of the most promising elements of its export potential.

Keywords: export potential, export activity, export-oriented companies, organizational and legal conditions. 